medRxiv preprint doi: https://doi.org/10.1101/2021.06.11.21258789; this version posted June 16, 2021. The copyright holder for this preprint (which was not certified by peer review) is the author/funder, who has granted medRxiv a license to display the preprint in perpetuity. It is made available under a CC-BY-NC-ND 4.0 International license .

\title{
Mycobacterium tuberculosis-specific T cell responses are impaired during late pregnancy with elevated biomarkers of tuberculosis risk postpartum
}

Authors: Aparajita Saha ${ }^{1,2}$, Jaclyn Escuduero ${ }^{2}$, Troy Layouni ${ }^{3}$, Barbra Richardson ${ }^{2,4}$, Sharon $\mathrm{Hou}^{2}$, Nelly Mugo ${ }^{5}$, Andrew Mujugira,6, Connie Celum ${ }^{1,2,7}$, Jared M. Baeten ${ }^{2,8}$ Jairam Lingappa $^{1,2,4}$, Grace C. John-Stewart ${ }^{1,2,7,9}$, Sylvia M. LaCourse ${ }^{1,2^{*}}$, Javeed A. Shah ${ }^{1,2,3^{\star}}$.

*Both authors contributed equally

Affiliations:

${ }^{1}$ Department of Medicine, University of Washington

2 Department of Global Health, University of Washington

${ }^{3}$ VA Puget Sound Health Care System

${ }^{4}$ Department of Biostatistics, University of Washington

${ }^{5}$ Kenya Medical Research Institute, Nairobi, Kenya

${ }^{6}$ Infectious Diseases Institute, Makerere University, Kampala, Uganda

7 Department of Pediatrics, University of Washington

${ }^{8}$ Gilead Sciences, Foster City

${ }^{9}$ Department of Epidemiology, University of Washington

Corresponding author: Javeed A. Shah, jashah@uw.edu; 206-543-8728

Author Contributions: AS: contributed to the design, data acquisition, analysis, and manuscript preparation. JE: data analysis, manuscript preparation, sample collection and transport, TL: statistical analysis, software, BR: data analysis, statistical support, manuscript editing; $\mathrm{SH} / \mathrm{HH}$ : sample transport, sample storage, database management, NM/AM: sample collection/storage, participant enrollment, CC/JB: cohort enrollment, funding, sample storage, manuscript editing, JL: cohort enrollment, sample storage, funding, manuscript editing, GJS: experimental design, data analysis, funding, manuscript editing, SL: experimental design, data analysis, grant funding, manuscript preparation and editing; JAS: experimental design, data analysis, grant funding, manuscript preparation and editing.

Grant Support: NICHD R21-HD098746, NIAID K23-AI120793, R01-Al136921, Bill \& Melinda Gates Foundation 26469, 41185, and 47674

Short Title: Pregnancy and Mtb T cell responses

Descriptor: 11.4 Mycobacterial Disease: Host Defenses

Total Word Count: 3534

This title has an online data supplement which is accessible from this issue's table of content online at www.atsjournals.org. 
medRxiv preprint doi: https://doi.org/10.1101/2021.06.11.21258789; this version posted June 16, 2021. The copyright holder for this preprint (which was not certified by peer review) is the author/funder, who has granted medRxiv a license to display the preprint in perpetuity.

It is made available under a CC-BY-NC-ND 4.0 International license .

\section{Abstract}

45 Rationale: Pregnancy is a risk factor for progression from latent tuberculosis infection (LTBI) to

46 symptomatic tuberculosis (TB). However, how dynamic immunologic changes in pregnancy

47 influence immune responses to M. tuberculosis (Mtb) is unknown.

48 Objectives: We performed a detailed characterization of Mtb-specific T cell responses of women

49 at high risk for Mtb infection, leveraging a biorepository of longitudinally samples collected

50 before, during, and after pregnancy in high HIV/TB burden settings.

51 Methods: We used specimens collected from women who became pregnant while enrolled in a

52 randomized controlled trial of pre-exposure prophylaxis for HIV prevention. We measured Mtb-

53 specific cytokines, CCR7 and CD45RA memory markers, and overall CD4+ and CD8+ T cell

54 activation from 49 women using COMPASS, a Bayesian statistical method for evaluating overall

55 antigen-specific $\mathrm{T}$ cell responses measured by flow cytometry.

56 Measurements and Main Results: 22 LTBI+ women, defined by flow cytometry, demonstrated

57 significantly diminished Mtb-specific CD4+ cytokine responses in the third trimester (COMPASS

58 score (PFS) 0.07) compared before (PFS 0.15), during (PFS 0.13 and 0.16), and after

59 pregnancy (PFS $0.14 ; p=0.0084$, Kruskal-Wallis test). Paradoxically, Mtb-specific CD8+

60 cytokine responses and nonspecifically activated CD38+HLA-DR+CD4+ T cells increased

61 during late pregnancy. Nonspecific T cell activation, a previously validated biomarker for

62 progression from LTBI to TB disease, was increased in LTBI+ women postpartum, compared

63 with LTBI- women.

64 Conclusions: Pregnancy-related functional T cell changes were most pronounced during late

65 pregnancy. Mtb-specific T cell changes during pregnancy and postpartum, increases in immune

66 activation may contribute to increased risk for TB progression in the postpartum period.

67 Abstract Word Count: 245

68 Keywords: $M$. tuberculosis, pregnancy, T cells, T cell memory, T cell activation 
medRxiv preprint doi: https://doi.org/10.1101/2021.06.11.21258789; this version posted June 16, 2021. The copyright holder for this preprint (which was not certified by peer review) is the author/funder, who has granted medRxiv a license to display the preprint in perpetuity.

It is made available under a CC-BY-NC-ND 4.0 International license .

\section{Introduction}

Tuberculosis (TB) disease in pregnancy and postpartum is associated with poor maternal and infant outcomes $(1,2)$. Recent large cohort studies demonstrate that pregnancy is associated with increased rates of tuberculosis disease (TB) up to six months postpartum $(3,4)$. However, the immune mechanisms underpinning this observation are not clear. Successful pregnancy requires dynamic alteration of the local immune environment (5-7). These adaptations to fetal development are accompanied by cell-specific systemic immune alterations (8). Pathogen-specific responses may be influenced by these systemic immune changes, which can alter disease risk (9-11). Understanding pathogen-specific changes to the immune response during pregnancy may improve efforts to prevent and control disease.

T cell responses are a critical aspect of Mtb host defense. Multiple lines of evidence, including studies in mouse and nonhuman primate studies of CD4+ T cell knockout or depletion, human genetic studies, and observational studies during HIV infection demonstrate that CD4+ T cells are essential for Mtb control (12-16). Prior data suggests that IFN $\gamma$ responses in CD4+ T cells are essential for Mtb protection (17). The frequency of CD4+ T cells simultaneously producing IL-2, TNF, and IFN $\gamma$ (e.g., that are polyfunctional) is correlated with Mtb protection (18). Other $T$ cell phenotypes, such as central memory cells $(T c m)$ and CD8+ $T$ cells, may contribute to Mtb host defense (19-22). Conversely, increased total numbers of nonspecifically activated HLA-DR+CD4+ T cells are a correlate of TB progression $(23,24)$. Since studies of pregnancy commonly begin enrollment during the first or second trimester of pregnancy, they are often unable to capture immune variation prior to and earlier in pregnancy. We leveraged a unique biorepository of samples and data collected longitudinally before, during, and after pregnancy from women in sub-Saharan Africa enrolled in a randomized controlled trial of pre- 
medRxiv preprint doi: https://doi.org/10.1101/2021.06.11.21258789; this version posted June 16, 2021. The copyright holder for this preprint (which was not certified by peer review) is the author/funder, who has granted medRxiv a license to display the preprint in perpetuity.

It is made available under a CC-BY-NC-ND 4.0 International license .

93 exposure prophylaxis for HIV prevention to evaluate the effects of various stages of pregnancy

94 on Mtb-specific T cell responses.

95

96 Methods

97 Study Population

98 The protocol for this study was approved by the University of Washington Human Subjects

99 Review Committee and ethics review committee at each study site. All participants provided

100 written informed consent in English or their native language. The Partners PrEP Study was a

101 randomized clinical trial of antiretroviral pre-exposure prophylaxis (PrEP) in HIV serodiscordant

102 couples (25). 4758 total participants were enrolled from 9 sites in Kenya and Uganda between

1032007 and 2012. Partners with HIV and CD4 cell count $\geq 250$, without history of AIDS-defining

104 diagnosis or current use of antiretroviral therapy (ART) were eligible. Participants without HIV

105 underwent monthly HIV testing from the parent trial and had urine pregnancy testing at

106 enrollment and monthly thereafter; women living with HIV (WLHIV) had urine collected quarterly.

107 WLHIV not already on ART who became pregnant were referred for prevention of maternal to

108 child transmission services. Participants were eligible for this analysis if they had at least two

109 samples available within 6 months prior to and during incident pregnancy. If available, additional

110 samples were tested from within 6 months postpartum. (Figure 1A). For participants with only

111 two timepoints available (before and during pregnancy), paired testing was done only on

112 participants with pregnancy samples from $\geq 20$ weeks gestation after interim evaluation of data

113 from participants with three time points samples. WLHIV received antiretrovirals for prevention

114 of maternal to child transmission of HIV, but not for treatment based on the guidelines at the 115 time.

116

117 Statistical Analysis 
medRxiv preprint doi: https://doi.org/10.1101/2021.06.11.21258789; this version posted June 16, 2021. The copyright holder for this preprint (which was not certified by peer review) is the author/funder, who has granted medRxiv a license to display the preprint in perpetuity.

It is made available under a CC-BY-NC-ND 4.0 International license .

118 We used the R package COMPASS to analyze the overall cytokine response of CD4+ and

119 CD8+ T cells and to determine cytokine-producing subsets. COMPASS uses a Bayesian

120 hierarchical framework to model all observed cell subsets and select those most likely to have

121 antigen-specific responses $(26,27)$. COMPASS provided a functional score (FS), which is the

122 proportion of antigen specific subsets detected among all possible ones, and polyfunctional

123 score (PFS), which is similar, but weighs the different subsets to favor subsets with higher

124 degrees of functionality. Our primary outcome of interest was the COMPASS PFS from CD4+

125 and CD8+ T cells of $\mathrm{LTBI}+$ women with preexisting $\mathrm{T}$ cell responses against Mtb, restimulated

126 with pooled peptides from the Mtb-specific antigens ESAT-6 and CFP10. Differences in median

127 values were compared among timepoints of interest using Kruskal-Wallis tests as the primary

128 analysis, followed by Dunn's test to compare individual groups. Samples from women with and

129 without HIV were measured together except where indicated.

131 Results

132 Cohort characteristics and timing of sample collection

133 We identified 70 participants with incident pregnancy. 49 of these met criteria for this

134 study, with paired samples collected during pregnancy and another, collected less than 6

135 months prior to the pregnancy. 17 participants had samples collected from 3 timepoints (pre-,

136 during-, and post-pregnancy). 32 participants had samples collected before and during

137 pregnancy (Figure 1A). A total of 117 samples with evaluable results were analyzed; 48 pre-

138 pregnancy (median 18.7 weeks [IQR 12.4-22.2), 47 during pregnancy, (median 26.9 weeks

139 gestation [IQR 12.7-30.9]); 22 post-partum (median 23.1 weeks [IQR 18.4-39.6]). The median

140 age of study participants was 26.4 years (IQR 23.2-31.1); 36.7\% (18/49) were WLHIV with

141 median CD4 766 cells $/ \mathrm{mm}^{3}$ [IQR 507-1070]) (Table 1).

142

143 Identification of LTBI+ participants using flow cytometry 
medRxiv preprint doi: https://doi.org/10.1101/2021.06.11.21258789; this version posted June 16, 2021. The copyright holder for this preprint (which was not certified by peer review) is the author/funder, who has granted medRxiv a license to display the preprint in perpetuity.

It is made available under a CC-BY-NC-ND 4.0 International license .

We identified individuals with LTBI using their first evaluable sample using a flow-based

145 assay as TST or IGRA were not performed during the original trial. We defined individuals as

$146 \mathrm{LTBI}+$ if their proportion of the frequency of IFN $\gamma+\mathrm{CD} 4+\mathrm{T}$ cells doubled after ESAT-6 and CFP-

14710 pooled peptide stimulation compared to DMSO. This measurement correlates well with

148 commercial IGRA tests (28-31). 22/49 (45\%) individuals were LTBI+ by this measure (Figure

149 1B). We found that increasing the threshold for positivity to three-fold above background

150 reduced the proportion of $\mathrm{LTBI}+$ individuals slightly, from 22 (44\%) to 19 (41\%). These

151 observations are similar in frequency to other studies of women of childbearing age in regions

152 with high Mtb burden (32). We used the initially identified more inclusive cutoff to ensure we

153 identified all individuals with pre-existing immune responses to Mtb. We identified three

154 individuals who were LTBI- at baseline but LTBI+ by their pregnancy visit. In these situations,

155 we included these individuals as LTBI+ from their first positive result onward.

157 CD4+ and CD8+ T cell frequency is consistent before, during, and after pregnancy

158 Our primary study objective was to identify the overall changes to the $\mathrm{T}$ cell response 159 using samples collected before, during, and after pregnancy among LTBI+ women. We first

160 identified the frequency of CD4+ and CD8+ T cells from samples collected before, during, and

161 after pregnancy (gating shown in Figure S1A). The frequency of CD4+ and CD8+ T cells was

162 similar over these time points (Figure 1B-C). In WLHIV, the frequency of CD4+ T cells was

163 lower than in women without HIV, irrespective of pregnancy status (Figure S1B) and CD8+ T

164 cell frequency was increased (Figure S1C). COMPASS FS and PFS of CD4+ T cells from all 165 samples strongly correlated with our LTBI measurements (Figure 1E-F).

166

167 Mtb-specific CD4+ $T$ cells polyfunctional responses decreased during the third trimester of 168 pregnancy 
medRxiv preprint doi: https://doi.org/10.1101/2021.06.11.21258789; this version posted June 16, 2021. The copyright holder for this preprint (which was not certified by peer review) is the author/funder, who has granted medRxiv a license to display the preprint in perpetuity.

It is made available under a CC-BY-NC-ND 4.0 International license .

Mtb induces a polyfunctional T cell response that may act independently of IFN $\gamma$, and

170 these cells are critical for Mtb control (33). In Mtb-specific CD4+ T cells, PFS was significantly

171 different before, during, and after pregnancy (Figure 2A, gating in Figure S2; $p=0.0084$,

172 Kruskal-Wallis test). PFS was significantly decreased in the third trimester compared with pre-

173 pregnancy $(p=0.0005)$, second trimester $(p=0.0034)$ and post-pregnancy $(p<0.017)$, but not

174 during the first trimester $(p=0.099$; Figure 2A). FS results were similar to PFS (Figure 2B). We

175 detected fewer Mtb-specific cytokine-producing subsets during third trimester, and very few

176 subsets producing multiple cytokines simultaneously (COMPASS heatmaps shown in Figure

177 S3A). We noted diminished single cytokine responses during the third trimester in IL-2+CD4+

178 cells compared with the second trimester (Figure S3B; $p=0.026$ ) which trended lower

179 compared with pre-pregnancy $(p=0.13)$, first trimester $(p=0.12)$ and post-pregnancy $(p=$

180 0.09). CD4+TNF+ or CD4+IFN $\gamma+$ responses were similar across pregnancy (Figure S3C-D).

181 Therefore, using COMPASS, we were able to detect changes to Mtb-specific T cell responses

182 that may be clinically important but not immediately detectable by analyzing single cytokines

183 separately.

184

$185 C D 4+T$ cell responsiveness to a mitogen is altered during the third trimester

186 Clinical laboratory tests for LTBI include mitogen controls to assess overall $\mathrm{T}$ cell

187 reactivity; impacts to mitogen induced CD4+ and CD8+ T cell responses during pregnancy

188 directly alter LTBI diagnostic test performance (34). We compared T cell responses after

189 stimulation with phorbol 12-myristate 13-acetate and ionomycin (PMA/ionomycin) over

190 pregnancy in all study participants. We evaluated these T cell responses using traditional flow

191 cytometry analysis, not COMPASS, as COMPASS is designed to detect antigen specific

192 responses observed at low frequency. The frequency of IL2+CD4+ T cells responding to

193 PMA/ionomycin were significantly changed over the duration of pregnancy (Figure 3A, p 
medRxiv preprint doi: https://doi.org/10.1101/2021.06.11.21258789; this version posted June 16, 2021. The copyright holder for this preprint (which was not certified by peer review) is the author/funder, who has granted medRxiv a license to display the preprint in perpetuity.

It is made available under a CC-BY-NC-ND 4.0 International license .

$194<0.0001$, Kruskal-Wallis test). IL-2+CD4+ responses in the third trimester were increased

195 compared to pre-pregnancy $(p=0.022)$, first trimester $(p=0.0006)$ and post-pregnancy $(p<$

196 0.0001). TNF+CD4+ responses were also significantly increased during the third trimester

197 compared to first trimester $(p=0.0073)$ and post-pregnancy $(p=0.0002 ;$ Figure $3 B, p=0.0011$

198 overall). IFN $\gamma+C D 4+$ cells decreased across pregnancy $(p=0.0036)$. The third trimester

199 response was significantly diminished compared to pre-pregnancy $(p=0.016)$, first trimester ( $p$

$200=0.026)$, second trimester $(p=0.049)$, and post-pregnancy (Figure $3 \mathrm{C} ; \mathrm{p}=0.0001)$. IL-2+,

$201 \mathrm{TNF}+$, and IFN $\gamma+\mathrm{CD} 4+\mathrm{T}$ cell frequencies were each significantly different before and after

202 pregnancy $(p=0.006, p=0.008$, and $p=0.04$, respectively), suggesting that systemic immune

203 alterations of pregnancy begin during the first trimester and persist for weeks to months after

204 birth. These data demonstrate distinct patterns of CD4+ T cell activation across pregnancy as

205 compared to Mtb-specific T cells.

Mtb-specific CD8+ T cells increase in activity during the second and third trimester of pregnancy

CD8+ $T$ cells contribute to Mtb host defense and are measured in LTBI diagnostic tests

$209(35,36)$, but little is known about how pregnancy impacts Mtb-specific CD8+ T cell responses.

210 We found low but detectable Mtb-specific CD8+ T cell cytokine responses in most samples from

211 LTBI+ participants (Figure S2, gating strategy). The PFS and FS in CD8+ T cells changed

212 significantly over the course of pregnancy (Figure 4A-B; $p=0.0033$ and $p=0.038$ respectively,

213 Kruskal-Wallis test). Median PFS in CD8+ T cells was nearly undetectable before pregnancy

214 and significantly increased in the second trimester compared with pre-pregnancy $(p=0.015)$,

215 the first trimester $(p=0.023)$, and post-pregnancy $(p=0.034)$. A similar trend was observed in

216 FS. The complexity of the CD8+ T cell response increased during the second and third

217 trimester, and we detected subsets producing multiple cytokines simultaneously (Figure S4A).

218 We were unable to detect shifts in IL-2, TNF, and IFN $\gamma+$ CD8+ T cell responses when evaluated 
medRxiv preprint doi: https://doi.org/10.1101/2021.06.11.21258789; this version posted June 16, 2021. The copyright holder for this preprint (which was not certified by peer review) is the author/funder, who has granted medRxiv a license to display the preprint in perpetuity.

It is made available under a CC-BY-NC-ND 4.0 International license .

219 singly, but we found a trend toward increased responses in each cytokine during the second

220 and third trimester (Figure S4B-D). Taken together, Mtb-specific CD8+ T cell responses

221 increased during the second and third trimester, while Mtb-specific CD4+ T cell responses

222 diminished during the same period.

Mitogen-induced TNF+ CD8+ T cell responses increase during pregnancy

We measured the changes in PMA/ionomycin-stimulated CD8+ T cell responses over

226 the course of pregnancy in all participants. IL-2+CD8+ responses were unchanged by

227 pregnancy trimester (Figure 5D; $p=0.14$, Kruskal-Wallis test). TNF+CD8+ T cell frequency

228 changed over the course of pregnancy (Figure 5E; $p=0.0084$ ) and increased in the third

229 trimester compared with the first trimester $(p=0.015)$ and post-pregnancy $(p=0.0018)$.

230 IFN $\gamma+\mathrm{CD} 8+\mathrm{T}$ cell frequencies were similar across pregnancy (Figure 5F). These responses

231 were distinct from the changes observed in Mtb-specific CD8+ T cells, where multiple subsets

232 increased in frequency during the second and third trimester.

234 Mtb-specific effector memory T cell populations diminish during the third trimester

235 T cells display cell surface markers CD45RA and CCR7 as markers of T cell memory 236 phenotype (37). Naïve (CCR7+CD45RA+), central memory (Tcm; CCR7+CD45RA-), and 237 effector memory (Tem; CCR7-CD45RA-) T cells display distinct functional profiles and tissue 238 homing sites, and Tcm are important for Mtb control (38-40). Naïve and Tcm produce little IFN

239 but Tem does not provide extended protection against disease. The frequency of total CD4+ 240 and CD8+ T cells expressing CD45RA and CCR7 did not change over pregnancy (Figure S5A-

241 C). We evaluated CD45RA and CCR7 expression in Mtb-specific CD4+ T cells, which were 242 ESAT-6 and CFP-10 peptide incubated, cytokine-producing, CD4+ T cells from LTBI+ 243 individuals. The proportion of Mtb-specific naïve and Tcm CD4+ T cells remained stable (Figure 
medRxiv preprint doi: https://doi.org/10.1101/2021.06.11.21258789; this version posted June 16, 2021. The copyright holder for this preprint (which was not certified by peer review) is the author/funder, who has granted medRxiv a license to display the preprint in perpetuity.

It is made available under a CC-BY-NC-ND 4.0 International license .

244 6A-B), but we observed reduced Tem frequency during the third trimester (Figure 6C, $p=$

$245 \quad 0.037$; Kruskal-Wallis test) compared to pre-pregnancy $(p=0.049)$, first trimester $(p=0.005)$,

246 second trimester $(p=0.014)$, and postpartum $(p=0.031)$. Viewed proportionally, naïve CD4+

247 cells increased while Tem decreased during the third trimester of pregnancy compared to the

248 first trimester, second trimester, and postpartum, without substantial changes to Tcm frequency

249 (Figure 6D). We did not detect adequate Mtb-specific CD8+ $\mathrm{T}$ cells to evaluate $\mathrm{T}$ cell

250 phenotypes in this population. In sum, Tem and IFN $\gamma+\mathrm{CD} 4+$ cells were reduced during the third

251 trimester, but without increases in the Tcm population, which is important for Mtb host defense

252 and may predict worsened Mtb control.

$254 \quad$ Nonspecific $T$ cell activation increases during pregnancy

255 Increased nonspecific CD4+ T cell activation is a correlate of risk for developing Mtb

256 disease $(41,42)$. We measured the frequency of HLA-DR+CD38+ CD4+ and CD8+ T cells

257 across pregnancy, using "flow minus one" controls (Figure S6A). The frequency of HLA-

258 DR+CD38+ CD4+ T cells significantly changed over pregnancy (Figure 7A; $p<0.0001$,

259 Kruskal-Wallis test), highest in the third trimester compared to pre-pregnancy $(p=0.0068)$, first

260 trimester $(p<0.0001)$, second trimester $(p=0.007)$, or postpartum (Figure $7 \mathbf{A} ; p<0.0001)$.

261 HLA-DR+CD38+ CD8+ T cell frequency also significantly changed similarly to CD4+ $T$ cells

262 (Figure 7B; $p<0.0001$, Kruskal-Wallis test). In both CD4+ and CD8+ T cells, activation markers

263 decreased from pre-pregnancy to the first trimester, and WLHIV demonstrated the greatest T

264 cell activation throughout pregnancy. Therefore, T cell activation decreases at the outset of

265 pregnancy, then increases over time until delivery.

266 We leveraged the observation that CD4+ $\mathrm{T}$ cell activation is a biomarker for TB risk to

267 evaluate if the immune changes of pregnancy might increase the risk for TB progression from

268 asymptomatic to symptomatic disease. We hypothesized that selective increases in nonspecific

269 T cell activation would be present in $\mathrm{LTBI}+$ women after pregnancy due to their increased risk 
medRxiv preprint doi: https://doi.org/10.1101/2021.06.11.21258789; this version posted June 16, 2021. The copyright holder for this preprint (which was not certified by peer review) is the author/funder, who has granted medRxiv a license to display the preprint in perpetuity.

It is made available under a CC-BY-NC-ND 4.0 International license .

270 for postpartum Mtb progression but not for LTBI- women. Pre-pregnancy, the proportion of

271 HLADR+CD38+CD4+ T cells was equivalent between LTBI- and LTBI+ individuals (Figure 7C).

272 Postpartum, LTBI+ individuals demonstrated significantly higher HLA-DR+CD38+ CD4+ T cells

273 as compared to LTBI- individuals (Figure 7D; $p=0.0026$, Mann-Whitney test). Immune

274 changes of pregnancy in $\mathrm{LTBI}+$ individuals may substantially contribute to overall $\mathrm{T}$ cell

275 activation in the postpartum period and predict increased risk for TB progression.

\section{Discussion}

278 In this study, we performed a comprehensive analysis of pregnancy stage on Mtb-

279 specific T cell phenotypes in sub-Saharan African women including women living with HIV.

280 These data are, to our knowledge, the first longitudinal assessment of systemic T cell responses

281 to Mtb in pregnancy that includes samples collected prior to pregnancy. Taken in sum, we found

282 that late pregnancy is associated with multiple changes to Mtb-specific T cell function: 1) overall

283 Mtb-specific CD4+ T cell responses diminished and simplified; 2) Mtb-specific CD4+ Tem, which

284 are cells that strongly produce IFN $\gamma$, decreased (37); 3) Mtb-specific CD8+ T cell responses

285 increased, and 4) nonspecific $T$ cell activation increased. (Figure 8). Nonspecific $T$ cell

286 activation increased in LTBI+ individuals compared to LTBI- individuals postpartum, despite

287 being equivalent pre-pregnancy. Increased nonspecific T cell activation, a correlate of risk for

288 Mtb disease in LTBI+ individuals, supports the observation that TB risk increases in the early

289 postpartum period (41). Together, late pregnancy induces complex changes in the known T cell

290 response to Mtb that have been associated with TB progression in other populations, and we

291 found that $\mathrm{LTBI}+$ women develop increased correlates of risk for TB in the immediate

292 postpartum period.

293

294 We observed distinct changes between Mtb-specific and more generalized mitogen

295 (PMA/ionomycin)-induced T cell cytokine responses. These results have direct implications 
medRxiv preprint doi: https://doi.org/10.1101/2021.06.11.21258789; this version posted June 16, 2021. The copyright holder for this preprint (which was not certified by peer review) is the author/funder, who has granted medRxiv a license to display the preprint in perpetuity.

It is made available under a CC-BY-NC-ND 4.0 International license .

296 toward the performance of LTBI diagnostics in pregnant women. Mtb-specific CD4+ T cell

297 responses decreased during the third trimester but increased in the second trimester, and Mtb-

298 specific CD8+ T cell responses were low but increased during the second and third trimester.

299 By contrast, overall mitogen responses in CD4+ T cells, especially IL-2 responses, increased

300 during late pregnancy. In other cohorts, discordance between the two commonest LTBI tests,

301 TST and IGRA, has been noted especially among women in the late second and early third

302 trimester, which may be partly due to the changes in the immune responses of pregnancy (34,

303 43). Part of the difference may be due to the absence of mitogen testing in most TSTs.

304 Understanding this discordance in pregnancy may have implications for TB progression. Among

305 those with positive IGRA but negative TST tests, Mtb-specific IL-2 responses associated with

306 postpartum TB progression from asymptomatic infection to symptomatic disease (44). In

307 combination, discordance between Mtb-specific and nonspecific immune responses may

308 contribute to increased false-negative LTBI testing during the third trimester and may contribute

309 to Mtb progression.

311 Conversely, we found that Mtb-specific CD8+ $\mathrm{T}$ cell responses increased during late

312 pregnancy when CD4+ T cell responses were diminished. The role of CD8+ T cells in TB

313 pathogenesis is uncertain. In children, Mtb-specific CD8+ T cell frequencies are correlated with

314 Mtb disease (45). In animals, CD8+ T cell responses correlate strongly with Mtb bacterial

315 burden in the lung $(46,47)$. CD8+ $T$ cells recognize antigens presented on major

316 histocompatibility complex I, which presents intracellular antigens. CD8+ T cells preferentially

317 recognize antigen-presenting cells with an increased bacterial burden (48). During active

318 intracellular infection, these responses may increase proportionally. It is unclear if some of these

319 responses reflect emerging TB disease or if there are general postpartum factors that enhance

320 CD8+ responses. These data suggest that CD8+ T cell responses may increase to compensate 
medRxiv preprint doi: https://doi.org/10.1101/2021.06.11.21258789; this version posted June 16, 2021. The copyright holder for this preprint (which was not certified by peer review) is the author/funder, who has granted medRxiv a license to display the preprint in perpetuity.

It is made available under a CC-BY-NC-ND 4.0 International license .

321 for diminished CD4+ T cell responses but may be unable to fully reproduce CD4+ T cell immune 322 control.

The strengths of this study include its longitudinal nature, including samples obtained

325 before, during, and after pregnancy. Most studies of the effects of pregnancy enroll women

326 during pregnancy and often focus on the second and third trimester, which do not capture pre-

327 pregnancy and first trimester periods. Several T cell phenotypes change significantly between

328 pre-pregnancy and the first trimester, and other phenotypes differed between pre-pregnancy

329 and postpartum. Local inflammation is critical for embryonic implantation, which suggests that

330 both local and systemic immune changes begin immediately and are prolonged post-partum

$331(49,50)$. Another strength of this study was the use of COMPASS. COMPASS analysis

332 revealed two findings that were not observable using standard data analysis techniques. This

333 sensitive analysis permitted us to observe the diminished complexity of the Mtb-specific CD4+ T

334 cell response during the third trimester and increases in overall CD8+ activity. Taken together,

335 no single cytokine response accounted for the changes to the Mtb-specific $T$ cell response,

336 suggesting broad changes in the functional capacity of $T$ cells responding to antigen during the

337 third trimester.

Weaknesses of this study include the lack of TB disease outcomes data. This study

340 used repository samples from a trial not originally designed to evaluate TB. However, we

341 performed detailed immune characterization of the changes to the Mtb-specific immune

342 response across pregnancy. Importantly, $\mathrm{LTBI}+$ women had increased $\mathrm{T}$ cell activation

343 postpartum, when compared with LTBI- women, which is a validated biomarker of TB disease

344 progression in other cohorts (23). IGRA or TST was not performed in the parent study, which

345 prevents correlation with clinically validated LTBI testing. However, the method we used in this

346 study to identify LTBI+ participants is a well-accepted alternate approach that correlates with 
medRxiv preprint doi: https://doi.org/10.1101/2021.06.11.21258789; this version posted June 16, 2021. The copyright holder for this preprint (which was not certified by peer review) is the author/funder, who has granted medRxiv a license to display the preprint in perpetuity.

It is made available under a CC-BY-NC-ND 4.0 International license .

347 LTBI diagnosis $(30,31)$. Generally, flow-based testing is more sensitive to detect prior exposure

348 to Mtb antigens than IGRA, so this approach permits us to evaluate a broader range of

349 individual immune responses. Errors introduced by the inclusion of individuals without

350 preexisting Mtb exposures are likely to reduce the sensitivity of this analysis to detect changes.

351 We performed sensitivity analyses by raising the threshold for LTBI+ identification, but this did

352 not substantially change the number of participants considered to have LTBI. Due to the limited

353 sample size of this study, we did not perform formal analysis to investigate the impact of HIV on

354 immune responses during pregnancy. Although HIV status was associated with reduced CD4+

355 T cell count and increased $T$ cell activation, we found immune changes of pregnancy were

356 generally independent of HIV status, though direct comparisons were limited due to small

357 sample size.

TB is the third leading cause of death among women of child-bearing age in high burden areas and is associated with morbidity and mortality in pregnant women and their children,

361 especially among those affected by HIV $(1,43)$. Our study provides evidence that systemic

362 changes in the $T$ cell response during the third trimester may contribute to increased risk for TB

363 progression. T cell cytokine responses are reduced and simplified, T cell memory phenotypes

364 skewed toward naïve phenotypes, and nonspecific activation is enhanced, which all are

365 independently associated with TB risk. Recent data suggest that isoniazid preventative therapy

366 is associated with adverse pregnancy outcomes, with a signal that this may occur more often if

367 initiated early in pregnancy (51). As such, late pregnancy, which is associated with key

368 immunologic changes for TB progression, may be an advantageous time to target for shorter

369 course regimens. Understanding host factors that place pregnant mothers at risk for TB may

370 provide insight into optimal public health strategies for TB control in this high-risk population.

\section{Acknowledgements}


medRxiv preprint doi: https://doi.org/10.1101/2021.06.11.21258789; this version posted June 16, 2021. The copyright holder for this preprint (which was not certified by peer review) is the author/funder, who has granted medRxiv a license to display the preprint in perpetuity.

It is made available under a CC-BY-NC-ND 4.0 International license.

373 The authors would like to thank the study participants and their families. We would like to

374 acknowledge the support of Harald Haugen on database management of clinical samples. We

375 would also like to acknowledge the clinical teams who obtained informed consent and collected

376 samples for this biorepository. We would also like to thank Chetan Seshadri for helpful technical

377 conversations. 
medRxiv preprint doi: https://doi.org/10.1101/2021.06.11.21258789; this version posted June 16, 2021. The copyright holder for this preprint (which was not certified by peer review) is the author/funder, who has granted medRxiv a license to display the preprint in perpetuity.

It is made available under a CC-BY-NC-ND 4.0 International license .

\section{$378 \quad$ Figure Legends}

379 Figure 1. Baseline Immune Characteristics Are Stable Across Pregnancy.

380 A) Flowchart of stored sample selection of participants with incidental pregnancies in the

381 Partners PrEP study.

382 B) Proportion of CD4+ T cells of all CD3+ cells, by pregnancy, trimester, and HIV status. Here

383 and throughout, Samples indicated with black circles are from HIV- donors, while gold triangles

384 are from WLHIV here and throughout this study.

385 C) Proportion of CD8+ T cells, stratified by pregnancy, trimester, and HIV status.

386 Pre-pregnancy sample $N=49 ; 1^{\text {st }}$ trimester $N=9,2^{\text {nd }}$ trimester $N=14 ; 3^{\text {rd }}$ trimester $N=24$;

387 postpartum $\mathrm{N}=22$. Black circles indicate HIV- study participants, while gold triangles indicate

388 WLHIV here and throughout this paper. Bars indicate median values. Statistical difference

389 between CD4 and CD8+ T cells was measured by Kruskal-Wallis test with sub-analysis

390 comparing column medians.

391 D) Fold change of the proportion of CD4+ T cells expressing IFN $\gamma$ after incubation with ESAT-6

392 and CFP-10 pooled peptides, compared to vehicle control.

393 E) COMPASS functional score (FS), stratified by LTBI status.

394 F) COMPASS polyfunctional score (PFS), stratified by LTBI status.

Figure 2. Mtb-specific CD4+ T cell responses are diminished during the third trimester of

397 pregnancy.

398 A) Polyfunctional scores (PFS) generated from COMPASS analysis, stratified by pregnancy

399 trimester. Black dots indicate an HIV- study participant, while gold triangles indicate a WLHIV.

400 Bars indicate median values. ${ }^{*} \mathrm{P}<0.05$, ${ }^{* *} \mathrm{P}<0.01,{ }^{* * *} \mathrm{P}<0.001$, Kruskal-Wallis test. Column-

401 to-column comparisons are made with Dunn's test.

402 B) Functional scores (FS) generated from COMPASS analysis, stratified by pregnancy

403 trimester. Black dots indicate an HIV- study participant, while gold triangles indicate a WLHIV. 
medRxiv preprint doi: https://doi.org/10.1101/2021.06.11.21258789; this version posted June 16, 2021. The copyright holder for this preprint (which was not certified by peer review) is the author/funder, who has granted medRxiv a license to display the preprint in perpetuity.

It is made available under a CC-BY-NC-ND 4.0 International license .

404 Bars indicate median values. ${ }^{*} \mathrm{P}<0.05$, ${ }^{* *} \mathrm{P}<0.01$, ${ }^{* * *} \mathrm{P}<0.001$, Kruskal-Wallis test. Column-

405 to-column comparisons are made with Dunn's test.

406

Figure 3. PMA/ionomycin-stimulated CD4+ T cell cytokine responses are dynamic across

pregnancy.

409 A-C) Proportion of A) IL-2+CD4+, B) TNF+CD4+, or C) IFN $\gamma+C D 4+$ T cells, stratified by

410 pregnancy status. Black dots indicate an HIV-study participant, while gold triangles indicate a

411 WLHIV. Bars indicate median values. ${ }^{*} \mathrm{P}<0.05$, ${ }^{* *} \mathrm{P}<0.01$, ${ }^{* *} \mathrm{P}<0.001$, GEE with estimating

412 equation, connected by overhead bar.

413 D-F) Proportion of D) IL-2+CD4+, E) TNF+CD4+, or F) IFN $\gamma+C D 4+$ T cells, stratified by

414 pregnancy trimester. Black dots indicate an HIV- study participant, while gold triangles indicate

415 an $\mathrm{HIV}+$ study participant. Bars indicate median values. ${ }^{*} \mathrm{P}<0.05,{ }^{* *} \mathrm{P}<0.01,{ }^{* *} \mathrm{P}<0.001$,

416 Overall significant by Kruskal-Wallis test demonstrated with top, thick line without overhangs.

417 Column-to-column comparisons are made with Dunn's test and shown with thinner bars with

418 overhangs.

420 Figure 4. Mtb-specific CD8+ T cell polyfunctionality increases during the second

421 trimester of pregnancy.

422 A) Polyfunctional scores (PFS) generated from COMPASS analysis, stratified by pregnancy

423 trimester. Black dots indicate an HIV- study participant, while gold triangles indicate a WLHIV.

424 Bars indicate median values. ${ }^{*} \mathrm{P}<0.05$, ${ }^{* *} \mathrm{P}<0.01$, ${ }^{* *} \mathrm{P}<0.001$, Kruskal-Wallis test. Column-

425 to-column comparisons are made with Dunn's test. Black dots indicate an HIV- study

426 participant, while gold triangles indicate a sample from WLHIV study participant.

427 B) Functional scores (FS) generated from COMPASS analysis, stratified by pregnancy 428 trimester. Black dots indicate an HIV- study participant, while gold triangles indicate a WLHIV. 
medRxiv preprint doi: https://doi.org/10.1101/2021.06.11.21258789; this version posted June 16, 2021. The copyright holder for this preprint (which was not certified by peer review) is the author/funder, who has granted medRxiv a license to display the preprint in perpetuity.

It is made available under a CC-BY-NC-ND 4.0 International license .

429 Bars indicate median values. ${ }^{*} \mathrm{P}<0.05$, ${ }^{* *} \mathrm{P}<0.01$, ${ }^{* * *} \mathrm{P}<0.001$, Kruskal-Wallis test. Column-

430 to-column comparisons are made with Dunn's test.

432 Figure 5. Cytokine responses in PMA/ionomycin-stimulated CD8+ T cells are stable

\section{3 during pregnancy.}

434 A-C) Proportion of A) IL-2+CD8+, B) TNF+CD8+, or C) IFN $\gamma+C D 8+T$ cells, stratified by

435 pregnancy status. Black dots indicate an HIV- study participant, while gold triangles indicate an

$436 \mathrm{HIV}+$ study participant. Bars indicate median values. ${ }^{*} \mathrm{P}<0.05,{ }^{* *} \mathrm{P}<0.01,{ }^{* * *} \mathrm{P}<0.001, \mathrm{GEE}$

437 with estimating equation, connected by overhead bar.

438 D-F) Proportion of D) IL-2+CD8+, E) TNF+CD8+, or F) IFN $\gamma+C D 8+$ T cells, stratified by 439 pregnancy trimester. Black dots indicate an HIV- study participant, while gold triangles indicate 440 an $\mathrm{HIV}+$ study participant. Bars indicate median values. ${ }^{*} \mathrm{P}<0.05,{ }^{* *} \mathrm{P}<0.01,{ }^{* *} \mathrm{P}<0.001$, 441 Kruskal-Wallis test. Column-to-column comparisons are made with Dunn's test.

443 Figure 6. Proportions of Mtb-specific naïve CD4+ T cells increase and effector memory T 444 cells decrease during the third trimester of pregnancy.

445 A-C) Overall proportion of A) naïve (CCR7+CD45RA+), B) central memory ( $T_{\mathrm{CM}}$; 446 CCR7+CD45RA-), and C) effector memory ( $\mathrm{T}_{\mathrm{EM}}$; CCR7-CD45RA-) among all cytokine447 producing CD4+ T cells after re-stimulation with ESAT-6 and CFP-10 antigens, stratified by 448 pregnancy status. Black dots indicate an HIV- study participant, while gold triangles indicate a 449 sample from WLHIV study participant. ${ }^{*} \mathrm{P}<0.05$, ${ }^{* *} \mathrm{P}<0.01$, ${ }^{* * *} \mathrm{P}<0.001$, Kruskal-Wallis test. 450 Column-to-column comparisons are made with Dunn's test.

451 D) Pie chart of Boolean-gated $T$ helper memory phenotype frequencies, comparing the third 452 trimester with other timepoints, connected by overhead bar. Blue arc indicates CCR7+ cells, red 453 arc indicates CD45RA+ cells. Red pie slice: Naïve CD4+ T cells (Naïve); blue pie slice: effector 
medRxiv preprint doi: https://doi.org/10.1101/2021.06.11.21258789; this version posted June 16, 2021. The copyright holder for this preprint (which was not certified by peer review) is the author/funder, who has granted medRxiv a license to display the preprint in perpetuity.

It is made available under a CC-BY-NC-ND 4.0 International license .

454 memory CD4+ T cells (Tem); gray slice: central memory T cell (Tcm); white slice: TEMRA cell

455 (TEMRA). ${ }^{*} \mathrm{P}<0.05,{ }^{* \star} \mathrm{P}<0.01,{ }^{\star \star \star} \mathrm{P}<0.001$, permutation test of 10000 iterations.

457 Figure 7. Nonspecific T cell activation increases during pregnancy and LTBI+ women

458 demonstrate increased T cell activation postpartum

459 A) Proportion of HLA-DR+CD38+ CD4+ T cells, stratified by pregnancy status.

460 B) Proportion of HLA-DR+CD38+ CD8+ T cells, stratified by pregnancy status.

461 C) Proportion of HLA-DR+CD38+ CD4+ T cells from samples collected pre-pregnancy, stratified

462 by LTBI status of the participant.

463 D) Proportion of HLA-DR+CD38+ CD4+ T cells from samples collected postpartum, stratified by

464 LTBI status of the participant. Black dots indicate an HIV-study participant, while gold triangles 465 indicate sample from WLHIV. Thick bars correspond to overall changes (Krukal-Wallis test).

466 Bars with overhangs indicate analysis of differences between columns (Dunn's test). Bars

467 indicate median values. ${ }^{*} \mathrm{P}<0.05$, ${ }^{* *} \mathrm{P}<0.01,{ }^{* *} \mathrm{P}<0.001$, Kruskal-Wallis test. Column-to-

468 column comparisons are made with Dunn's test in multiple group comparisons or Mann-Whitney

469 U-test for tests between two groups.

471 Figure 8. Summary of overall Mtb-specific $\mathbf{T}$ cell responses during differing stages of

472 pregnancy. We observed distinct changes in Mtb-specific T cell responses as compared to

473 mitogen-stimulated T cells. Arrows indicate the overall frequency of the responses measured. A

474 downward arrow followed by an upward arrow indicates diminished IL-2/TNF responses with

475 simultaneous increases in IFN $\gamma+$ cell frequency, and an upward arrow followed by a downward

476 arrow indicates increases in IL-2/TNF+ T cell frequency with decreases in IFN $\gamma+$ responses. 
medRxiv preprint doi: https://doi.org/10.1101/2021.06.11.21258789; this version posted June 16, 2021. The copyright holder for this preprint (which was not certified by peer review) is the author/funder, who has granted medRxiv a license to display the preprint in perpetuity. It is made available under a CC-BY-NC-ND 4.0 International license .

\section{References}

1. Mathad JS, Gupta A. Tuberculosis in pregnant and postpartum women: epidemiology, management, and research gaps. Clin Infect Dis 2012; 55: 15321549.

2. Mathad JS, LaCourse SM, Gupta A. TB prevention strategies and unanswered questions for pregnant and postpartum women living with HIV: the need for improved evidence. J Int AIDS Soc 2020; 23: e25481.

3. Jonsson J, Kuhlmann-Berenzon S, Berggren I, Bruchfeld J. Increased risk of active tuberculosis during pregnancy and postpartum: a register-based cohort study in Sweden. Eur Respir J 2020; 55.

4. Zenner D, Kruijshaar ME, Andrews N, Abubakar I. Risk of tuberculosis in pregnancy: a national, primary care-based cohort and self-controlled case series study. Am J Respir Crit Care Med 2012; 185: 779-784.

5. Mor G, Aldo P, Alvero AB. The unique immunological and microbial aspects of pregnancy. Nat Rev Immunol 2017; 17: 469-482.

6. Erlebacher A. Immunology of the Maternal-Fetal Interface. Annual Review of Immunology 2013; 31: 387-411.

7. Shah NM, Herasimtschuk AA, Boasso A, Benlahrech A, Fuchs D, Imami N, Johnson MR. Changes in T Cell and Dendritic Cell Phenotype from Mid to Late Pregnancy Are Indicative of a Shift from Immune Tolerance to Immune Activation. Front Immunol 2017; 8: 1138.

8. Aghaeepour N, Ganio EA, Mcllwain D, Tsai AS, Tingle M, Van Gassen S, Gaudilliere DK, Baca Q, McNeil L, Okada R, Ghaemi MS, Furman D, Wong RJ, Winn VD, 
medRxiv preprint doi: https://doi.org/10.1101/2021.06.11.21258789; this version posted June 16, 2021. The copyright holder for this preprint (which was not certified by peer review) is the author/funder, who has granted medRxiv a license to display the preprint in perpetuity. It is made available under a CC-BY-NC-ND 4.0 International license .

Druzin ML, El-Sayed YY, Quaintance C, Gibbs R, Darmstadt GL, Shaw GM, Stevenson DK, Tibshirani R, Nolan GP, Lewis DB, Angst MS, Gaudilliere B. An immune clock of human pregnancy. Sci Immunol 2017; 2.

9. Kourtis AP, Read JS, Jamieson DJ. Pregnancy and Infection. New England Journal of Medicine 2014; 370: 2211-2218.

10. Racicot K, Mor G. Risks associated with viral infections during pregnancy. J Clin Invest 2017; 127: 1591-1599.

11. Kay AW, Fukuyama J, Aziz N, Dekker CL, Mackey S, Swan GE, Davis MM, Holmes S, Blish CA. Enhanced natural killer-cell and T-cell responses to influenza A virus during pregnancy. Proc Natl Acad Sci U S A 2014; 111: 14506-14511.

12. Leveton C, Barnass S, Champion B, Lucas S, De Souza B, Nicol M, Banerjee D, Rook G. T-cell-mediated protection of mice against virulent Mycobacterium tuberculosis. Infection and immunity 1989; 57: 390-395.

514 13. Sakai S, Mayer-Barber KD, Barber DL. Defining features of protective CD4 T cell responses to Mycobacterium tuberculosis. Curr Opin Immunol 2014; 29: 137-

517 14. Müller I, Cobbold S, Waldmann H, Kaufmann S. Impaired resistance to Mycobacterium tuberculosis infection after selective in vivo depletion of L3T4+ and Lyt-2+ T cells. Infection and immunity 1987; 55: 2037-2041. depletion exacerbates acute Mycobacterium tuberculosis while reactivation of latent infection is dependent on severity of tissue depletion in cynomolgus macaques. AIDS Res Hum Retroviruses 2012; 28: 1693-1702. 
medRxiv preprint doi: https://doi.org/10.1101/2021.06.11.21258789; this version posted June 16, 2021. The copyright holder for this preprint (which was not certified by peer review) is the author/funder, who has granted medRxiv a license to display the preprint in perpetuity. It is made available under a CC-BY-NC-ND 4.0 International license .

524 16. Badri M, Wilson D, Wood R. Effect of highly active antiretroviral therapy on incidence of tuberculosis in South Africa: a cohort study. The Lancet 2002; 359:

17. Sakai S, Kauffman KD, Sallin MA, Sharpe AH, Young HA, Ganusov VV, Barber DL. 2059-2064.

18. Forbes EK, Sander C, Ronan EO, McShane H, Hill AV, Beverley PC, Tchilian EZ. Multifunctional, high-level cytokine-producing Th1 cells in the lung, but not spleen, correlate with protection against Mycobacterium tuberculosis aerosol

19. Lindenstrom T, Knudsen NP, Agger EM, Andersen P. Control of chronic mycobacterium tuberculosis infection by CD4 KLRG1- IL-2-secreting central memory cells. J Immunol 2013; 190: 6311-6319.

20. Andersen $\mathrm{P}$, Urdahl KB. TB vaccines; promoting rapid and durable protection in the lung. Curr Opin Immunol 2015; 35: 55-62.

21. Grotzke JE, Lewinsohn DM. Role of CD8(+) T lymphocytes in control of

542 22. Lancioni C, Nyendak M, Kiguli S, Zalwango S, Mori T, Mayanja-Kizza H, Balyejusa

543 S, Null M, Baseke J, Mulindwa D, Byrd L, Swarbrick G, Scott C, Johnson DF, $544 \quad$ Malone L, Mudido-Musoke P, Boom WH, Lewinsohn DM, Lewinsohn DA. CD8+ T cells provide an immunologic signature of tuberculosis in young children. $A m \mathrm{~J}$ 
medRxiv preprint doi: https://doi.org/10.1101/2021.06.11.21258789; this version posted June 16, 2021. The copyright holder for this preprint (which was not certified by peer review) is the author/funder, who has granted medRxiv a license to display the preprint in perpetuity. It is made available under a CC-BY-NC-ND 4.0 International license .

23. Fletcher HA, Snowden MA, Landry B, Rida W, Satti I, Harris SA, Matsumiya M, Tanner R, O'Shea MK, Dheenadhayalan V, Bogardus L, Stockdale L, Marsay L, Chomka A, Harrington-Kandt R, Manjaly-Thomas ZR, Naranbhai V, Stylianou E, Darboe F, Penn-Nicholson A, Nemes E, Hatherill M, Hussey G, Mahomed H, Tameris M, McClain JB, Evans TG, Hanekom WA, Scriba TJ, McShane H. T-cell activation is an immune correlate of risk in BCG vaccinated infants. Nat Commun 2016; 7: 11290.

24. Adekambi T, Ibegbu CC, Cagle S, Kalokhe AS, Wang YF, Hu Y, Day CL, Ray SM, Rengarajan J. Biomarkers on patient $\mathrm{T}$ cells diagnose active tuberculosis and monitor treatment response. J Clin Invest 2015; 125: 1827-1838.

25. Baeten JM, Donnell D, Ndase P, Mugo NR, Campbell JD, Wangisi J, Tappero JW, Bukusi EA, Cohen CR, Katabira E, Ronald A, Tumwesigye E, Were E, Fife KH, Kiarie J, Farquhar C, John-Stewart G, Kakia A, Odoyo J, Mucunguzi A, NakkuJoloba E, Twesigye R, Ngure K, Apaka C, Tamooh H, Gabona F, Mujugira A, Panteleeff D, Thomas KK, Kidoguchi L, Krows M, Revall J, Morrison S, Haugen H, Emmanuel-Ogier M, Ondrejcek L, Coombs RW, Frenkel L, Hendrix C, Bumpus NN, Bangsberg D, Haberer JE, Stevens WS, Lingappa JR, Celum C. Antiretroviral Prophylaxis for HIV Prevention in Heterosexual Men and Women. New England Journal of Medicine 2012; 367: 399-410.

26. Shah JA, Musvosvi M, Shey M, Horne DJ, Wells RD, Peterson GJ, Cox JS, Daya M, Hoal EG, Lin L, Gottardo R, Hanekom WA, Scriba TJ, Hatherill M, Hawn TR. A Functional TOLLIP Variant is Associated with BCG-Specific Immune Responses and Tuberculosis. Am J Respir Crit Care Med 2017. 
medRxiv preprint doi: https://doi.org/10.1101/2021.06.11.21258789; this version posted June 16, 2021. The copyright holder for this preprint (which was not certified by peer review) is the author/funder, who has granted medRxiv a license to display the preprint in perpetuity. It is made available under a CC-BY-NC-ND 4.0 International license .

27. Lin L, Finak G, Ushey K, Seshadri C, Hawn TR, Frahm N, Scriba TJ, Mahomed H, Hanekom W, Bart PA, Pantaleo G, Tomaras GD, Rerks-Ngarm S, Kaewkungwal J, Nitayaphan S, Pitisuttithum P, Michael NL, Kim JH, Robb ML, O'Connell RJ, Karasavvas N, Gilbert P, S CDR, McElrath MJ, Gottardo R. COMPASS identifies T-cell subsets correlated with clinical outcomes. Nat Biotechnol 2015; 33: 610616.

28. Tesfa L, Koch FW, Pankow W, Volk HD, Kern F. Confirmation of Mycobacterium tuberculosis infection by flow cytometry after ex vivo incubation of peripheral blood T cells with an ESAT-6-derived peptide pool. Cytometry Part B: Clinical Cytometry: The Journal of the International Society for Analytical Cytology 2004; 60: 47-53.

29. Papageorgiou CV, Anastasopoulos A, Ploussi M, Leventopoulos M, Karabela S, Fotiadis K, Papavasileiou A, Vogiatzakis E, loakeimidis D, Gritzapis AD, Poulakis $\mathrm{N}$. Flow cytometry analysis of CD4+IFN-gamma+ T-cells for the diagnosis of mycobacterium tuberculosis infection. Cytometry B Clin Cytom 2016; 90: 303311.

30. Lee J, Lee SY, Won DI, Cha SI, Park JY, Kim CH. Comparison of whole-blood interferon-gamma assay and flow cytometry for the detection of tuberculosis infection. J Infect 2013; 66: 338-345.

31. Sauzullo I, Scrivo R, Mengoni F, Ermocida A, Coppola M, Valesini G, Vullo V, Mastroianni CM. Multi-functional flow cytometry analysis of CD4+ T cells as an immune biomarker for latent tuberculosis status in patients treated with tumour necrosis factor (TNF) antagonists. Clin Exp Immunol 2014; 176: 410-417. 
medRxiv preprint doi: https://doi.org/10.1101/2021.06.11.21258789; this version posted June 16, 2021. The copyright holder for this preprint (which was not certified by peer review) is the author/funder, who has granted medRxiv a license to display the preprint in perpetuity. It is made available under a CC-BY-NC-ND 4.0 International license .

593 32. Mathad JS, Gupta A. Tuberculosis in Pregnant and Postpartum Women: $594 \quad$ Epidemiology, Management, and Research Gaps. Clinical Infectious Diseases 2012; 55: 1532-1549.

596 33. Lu LL, Smith MT, Yu KKQ, Luedemann C, Suscovich TJ, Grace PS, Cain A, Yu WH, McKitrick TR, Lauffenburger D, Cummings RD, Mayanja-Kizza H, Hawn TR, Boom WH, Stein CM, Fortune SM, Seshadri C, Alter G. IFN- $y$-independent

34. LaCourse SM, Cranmer LM, Matemo D, Kinuthia J, Richardson BA, Horne DJ, immune markers of Mycobacterium tuberculosis exposure. Nat Med 2019; 25: John-Stewart G. Effect of Pregnancy on Interferon Gamma Release Assay and Tuberculin Skin Test Detection of Latent TB Infection Among HIV-Infected Women in a High Burden Setting. J Acquir Immune Defic Syndr 2017; 75: 128136.

35. Lin PL, Flynn JL. CD8 T cells and Mycobacterium tuberculosis infection. Semin Immunopathol 2015; 37: 239-249.

36. Tsuyuzaki M, Igari H, Okada N, Suzuki K. Role of CD8 T-cell in immune response to

37. Seder RA, Darrah PA, Roederer M. T-cell quality in memory and protection: implications for vaccine design. Nat Rev Immunol; 2008. p. 247-258.

613 38. Jameson SC, Masopust D. Understanding Subset Diversity in T Cell Memory. 
medRxiv preprint doi: https://doi.org/10.1101/2021.06.11.21258789; this version posted June 16, 2021. The copyright holder for this preprint (which was not certified by peer review) is the author/funder, who has granted medRxiv a license to display the preprint in perpetuity. It is made available under a CC-BY-NC-ND 4.0 International license .

615 39. Lindenstrøm T, Knudsen NPH, Agger EM, Andersen P. Control of chronic 616 Mycobacterium tuberculosis infection by CD4 KLRG1- IL-2-secreting central memory cells. The Journal of Immunology 2013; 190: 6311-6319.

618 40. Vogelzang A, Perdomo C, Zedler U, Kuhlmann S, Hurwitz R, Gengenbacher M, Kaufmann SH. Central memory CD4+ T cells are responsible for the recombinant bacillus Calmette-Guerin $\Delta$ ureC:: hly vaccine's superior protection against tuberculosis. The Journal of infectious diseases 2014; 210: 1928-1937.

41. Fletcher HA, Snowden MA, Landry B, Rida W, Satti I, Harris SA, Matsumiya M, Tanner R, O'Shea MK, Dheenadhayalan V, Bogardus L, Stockdale L, Marsay L, Chomka A, Harrington-Kandt R, Manjaly-Thomas ZR, Naranbhai V, Stylianou E, Tameris M, McClain JB, Evans TG, Hanekom WA, Scriba TJ, McShane H. T-cell activation is an immune correlate of risk in BCG vaccinated infants. Nat Commun 2016; 7: 11290.

42. Arenas-Hernandez M, Romero R, Xu Y, Panaitescu B, Garcia-Flores V, Miller D, Ahn H, Done B, Hassan SS, Hsu CD, Tarca AL, Sanchez-Torres C, GomezLopez N. Effector and Activated T Cells Induce Preterm Labor and Birth That Is Chopade K, Suryavanshi N, Deshpande P, Kulkarni V, Glesby MJ, Fitzgerald D, Bharadwaj R, Sambarey P, Gupta A. Pregnancy differentially impacts performance of latent tuberculosis diagnostics in a high-burden setting. PLoS One 2014; 9: e92308. 
medRxiv preprint doi: https://doi.org/10.1101/2021.06.11.21258789; this version posted June 16, 2021. The copyright holder for this preprint (which was not certified by peer review) is the author/funder, who has granted medRxiv a license to display the preprint in perpetuity. It is made available under a CC-BY-NC-ND 4.0 International license .

44. Mathad JS, Bhosale R, Balasubramanian U, Kanade S, Mave V, Suryavanshi N, Gupte N, Joshi S, Chandanwale A, Dupnik KM, Kulkarni V, Deshpande P, Fitzgerald DW, Gupta A. Quantitative IFN-gamma and IL-2 Response Associated with Latent Tuberculosis Test Discordance in HIV-infected Pregnant Women. Am J Respir Crit Care Med 2016; 193: 1421-1428.

45. Lancioni C, Nyendak M, Kiguli S, Zalwango S, Mori T, Mayanja-Kizza H, Balyejusa S, Null M, Baseke J, Mulindwa D, Byrd L, Swarbrick G, Scott C, Johnson DF, Malone L, Mudido-Musoke P, Boom WH, Lewinsohn DM, Lewinsohn DA, Unit TR. CD8+ T Cells Provide an Immunologic Signature of Tuberculosis in Young Children. Am J Resp Crit Care 2012; 185: 206-212.

46. Lewinsohn DM, Tydeman IS, Frieder M, Grotzke JE, Lines RA, Ahmed S, Prongay KD, Primack SL, Colgin LMA, Lewis AD, Lewinsohn DA. High resolution radiographic and fine immunologic definition of TB disease progression in the rhesus macaque. Microbes and Infection 2006; 8: 2587-2598.

47. Billeskov R, Vingsbo-Lundberg C, Andersen P, Dietrich J. Induction of CD8 T Cells against a Novel Epitope in TB10.4: Correlation with Mycobacterial Virulence and the Presence of a Functional Region of Difference-1. The Journal of Immunology 2007; 179: 3973-3981.

48. Lewinsohn DA, Heinzel AS, Gardner JM, Zhu L, Alderson MR, Lewinsohn DM. Mycobacterium tuberculosis-specific CD8+ T Cells Preferentially Recognize Heavily Infected Cells. Am J Resp Crit Care 2003; 168: 1346-1352. 
medRxiv preprint doi: https://doi.org/10.1101/2021.06.11.21258789; this version posted June 16, 2021. The copyright holder for this preprint (which was not certified by peer review) is the author/funder, who has granted medRxiv a license to display the preprint in perpetuity. It is made available under a CC-BY-NC-ND 4.0 International license .

659 49. Zenclussen AC, Hämmerling GJ. Cellular Regulation of the Uterine 660 Microenvironment That Enables Embryo Implantation. Front Immunol 2015; 6: $661 \quad 321$.

662 50. Gnainsky Y, Granot I, Aldo P, Barash A, Or Y, Mor G, Dekel N. Biopsy-induced inflammatory conditions improve endometrial receptivity: the mechanism of action. Reproduction 2015; 149: 75-85.

665 51. Gupta A, Montepiedra G, Aaron L, Theron G, McCarthy K, Bradford S, Chipato T, 666 Vhembo T, Stranix-Chibanda L, Onyango-Makumbi C, Masheto GR, Violari A, 667 Mmbaga BT, Aurpibul L, Bhosale R, Mave V, Rouzier V, Hesseling A, Shin K, 668 Zimmer B, Costello D, Sterling TR, Chakhtoura N, Jean-Philippe P, Weinberg A, 669 Team IPTBAS. Isoniazid Preventive Therapy in HIV-Infected Pregnant and Postpartum Women. New England Journal of Medicine 2019; 381: 1333-1346. 


\begin{tabular}{|c|c|c|c|c|c|}
\hline & & & & \multirow[b]{2}{*}{$\begin{array}{c}\mathbf{R R} \\
(95 \% \mathrm{Cl})\end{array}$} & \multirow[b]{2}{*}{$\mathbf{p}$} \\
\hline Characteristic & $\begin{array}{c}\text { Overall } \\
\text { Median (IQR) or } \\
n(\%)\end{array}$ & $\begin{array}{c}\text { LTBI+ }^{*} \\
\text { Median (IQR) or } \\
n(\%)\end{array}$ & $\begin{array}{c}\text { LTBI- } \\
\text { Median (IQR) or } \\
n(\%)\end{array}$ & & \\
\hline Baseline & $\mathrm{N}=49^{* *}$ & $\mathrm{~N}=19$ & $\mathrm{~N}=30$ & & \\
\hline Age (years) & $26.4(23.2-31.3)$ & $26.8(23.2-31.1)$ & $26.2(22.7-31.5)$ & $1.02(0.94-1.10)$ & 0.624 \\
\hline WLHIV & $18(36.7)$ & $6(31.6)$ & $12(40.0)$ & $0.79(0.36-1.74)$ & 0.565 \\
\hline CD4 (cells $/ \mathrm{mm}^{3}$ ) & 765.5 (507-1070) & $868.5(588-1272)$ & $730.5(476.5-1042)$ & $1.00(1.00-1.00)$ & 0.258 \\
\hline Samples & $\mathrm{N}=117$ & $\mathrm{~N}=48$ & $\mathrm{~N}=69$ & & \\
\hline Pregnancy stage & & & & $1.10(0.83-1.47)$ & 0.496 \\
\hline Pre-pregnancy^ & $48(41.0)$ & $18(37.5)$ & $30(43.5)$ & & \\
\hline Pregnancy & $47(40.2)$ & $20(41.7)$ & $27(39.1)$ & $0.77(0.52-1.14)$ & 0.184 \\
\hline $1^{\mathrm{st}}$ trimester $(0$ to $<14$ weeks $)$ & $9(19.2)$ & $5(25.0)$ & $4(14.8)$ & & \\
\hline $2^{\text {nd }}$ trimester $(14$ to $<28$ weeks $)$ & $14(29.8)$ & $7(35.0)$ & $7(25.9)$ & & \\
\hline $3^{\text {rd }}$ trimester $(\geq 28$ weeks $)$ & $24(51.1)$ & $8(40.0)$ & $16(59.3)$ & & \\
\hline Post-pregnancy ${ }^{\star \star \star}$ & $22(18.8)$ & $10(20.8)$ & $12(17.4)$ & & \\
\hline \multicolumn{6}{|l|}{$\begin{array}{l}\text { Timing of sample collection } \\
\text { (weeks) }\end{array}$} \\
\hline Pre-pregnancy & $-18.7(-22.2--12.4)$ & $-18.3(-22.3--11.7)$ & $-18.8(-22.1--13.1)$ & $1.00(0.96-1.03)$ & 0.836 \\
\hline During pregnancy & $26.9(12.7-30.9)$ & $18.9(11.7-28.1)$ & $28.7(22.4-32.0)$ & $0.97(0.94-1.00)$ & 0.077 \\
\hline Post-pregnancy & $23.1(18.4-39.6)$ & $19.5(17.3-45.6)$ & $30.5(21.4-38.7)$ & $1.00(0.97-1.03)$ & 0.980 \\
\hline
\end{tabular}
$23.1(18.4-39.6)$

$30.5(21.4-38.7)$

* LTBI diagnosis determined by $2 x$ increase of frequency of IFNg+CD4+ cells after stimulation with Mtb antigens over control

$675{ }^{* *}$ Includes one participant whose pre-pregnancy sample was unevaluable

$676{ }^{* * *}$ Up to six months after delivery

677 Samples collected up to six months before date of conception 
medRxiv preprint doi: https://doi.org/10.1101/2021.06.11.21258789; this version posted June 16, 2021. The copyright holder for this preprint (which was not certified by peer review) is the author/funder, who has granted medRxiv a license to display the preprint in perpetuity. 

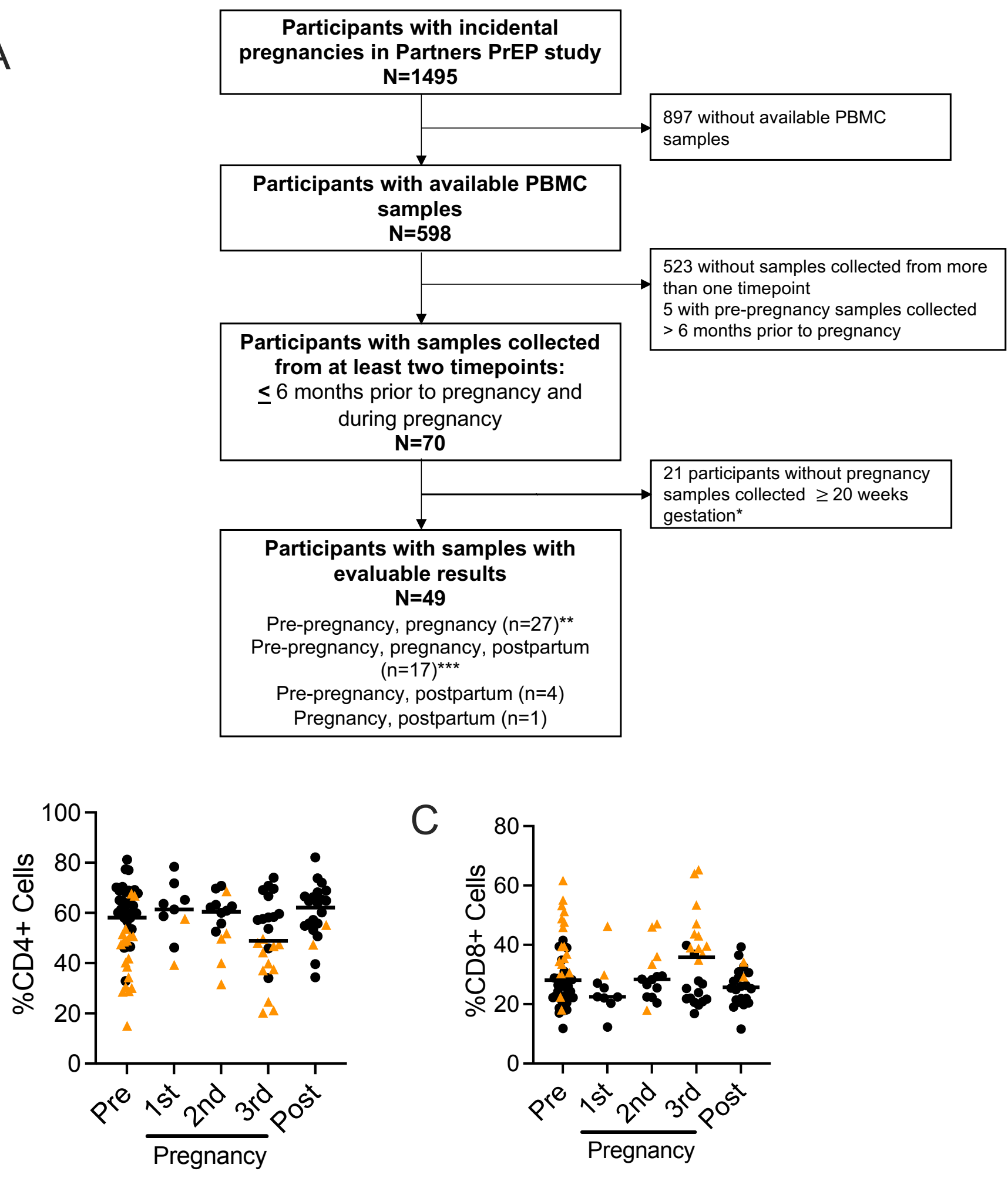

D

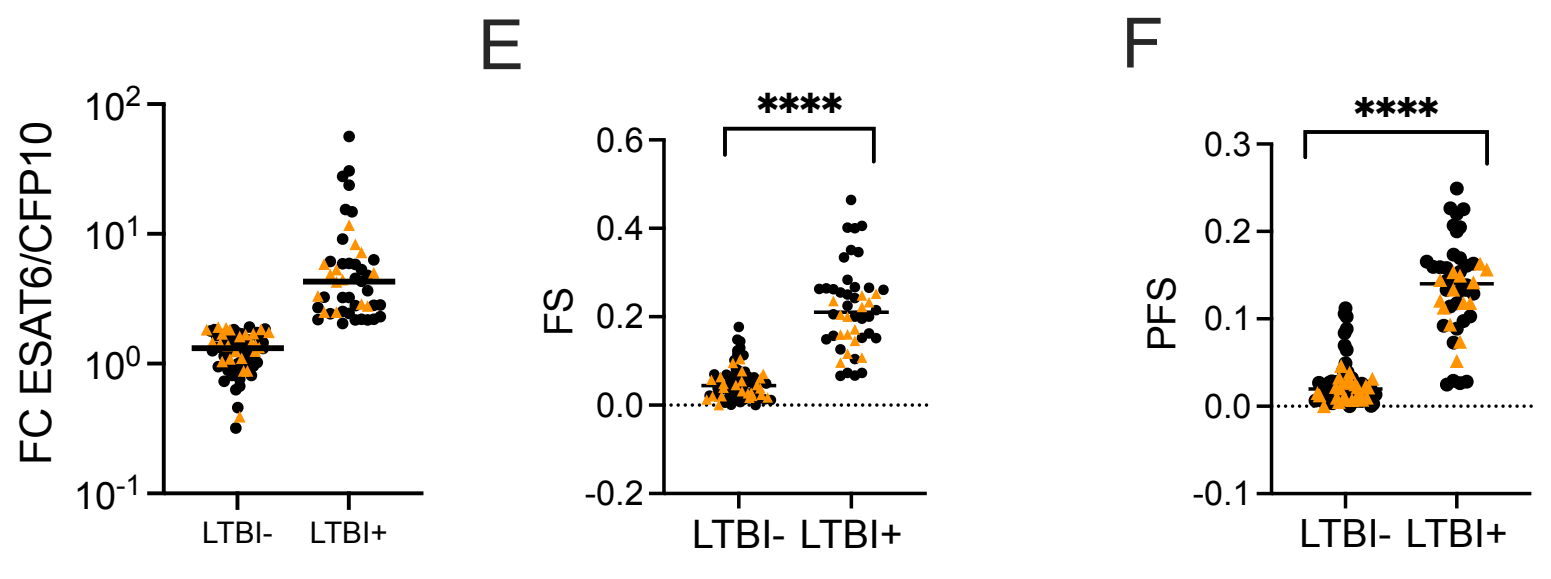


A

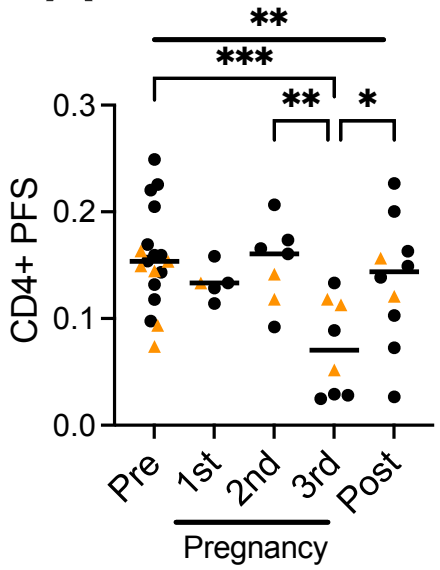

Figure 2

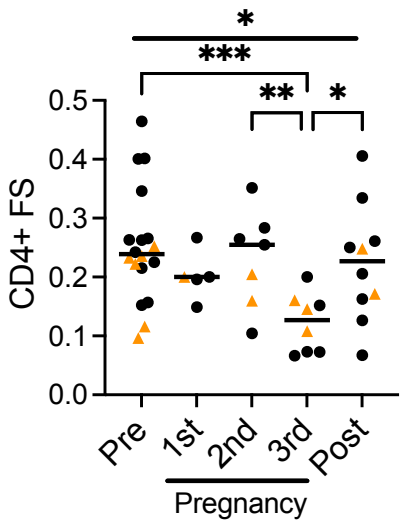




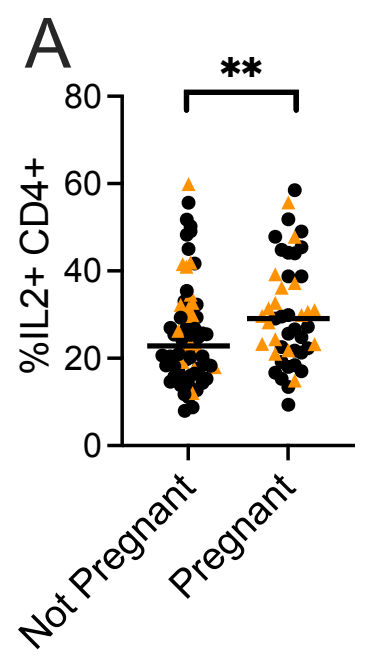

B
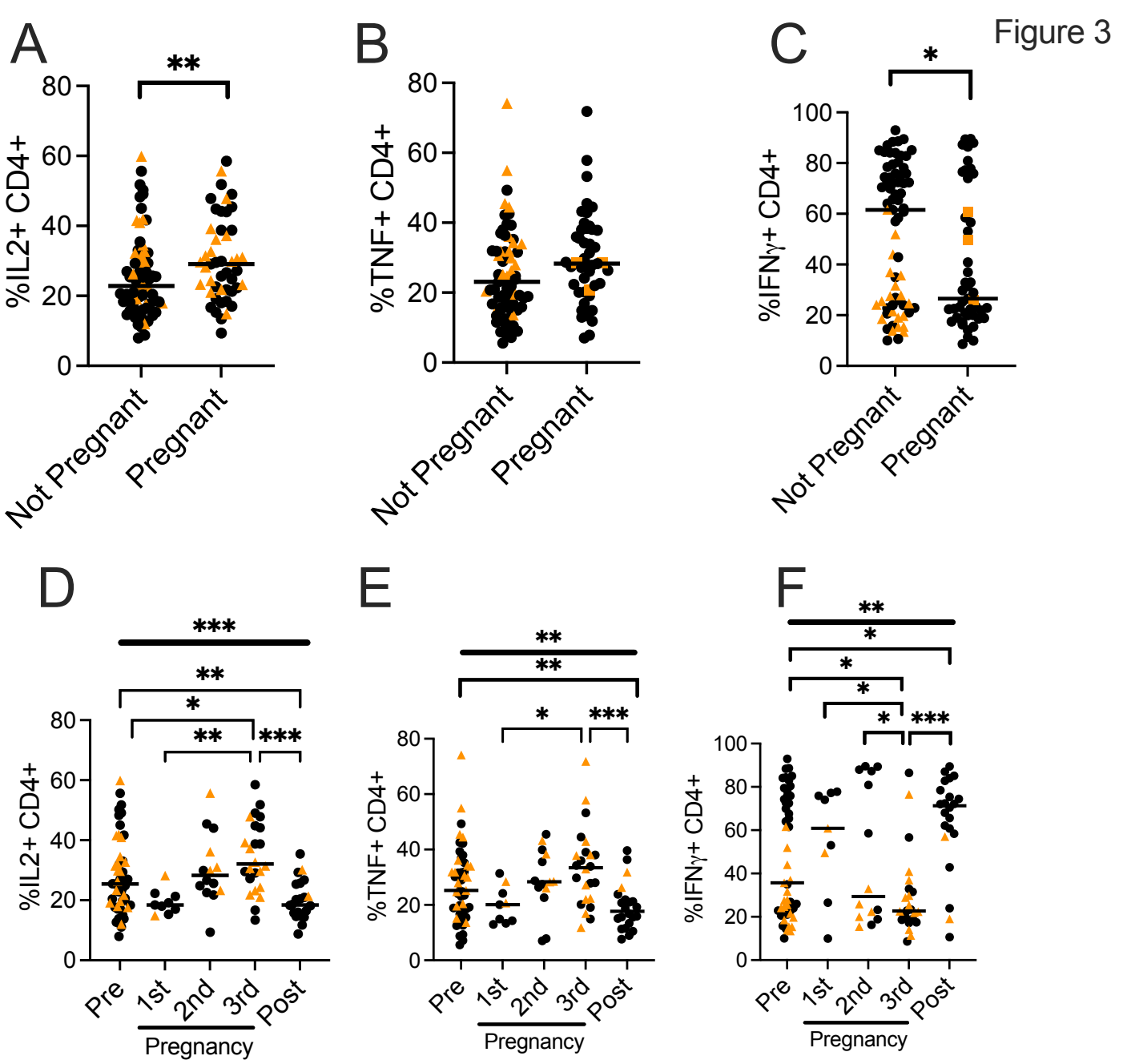

E
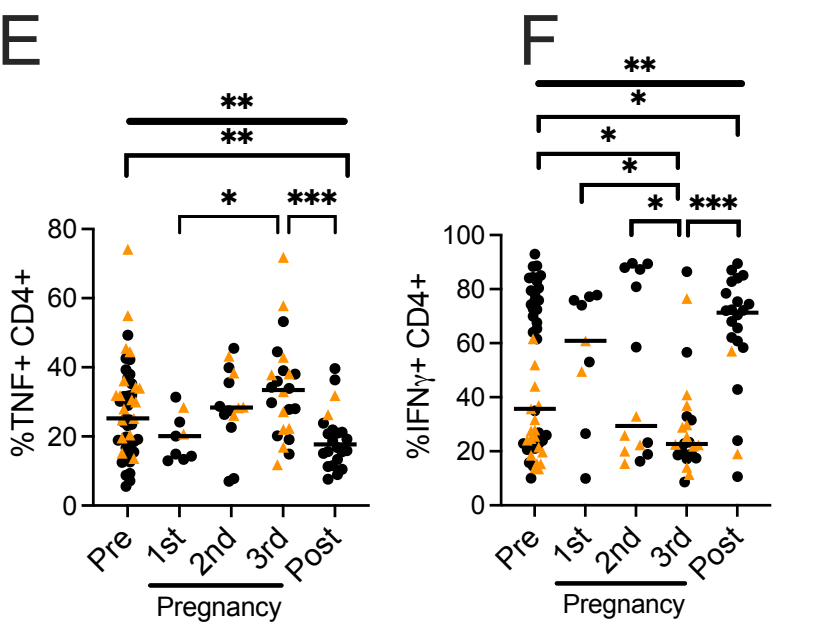
Figure 4
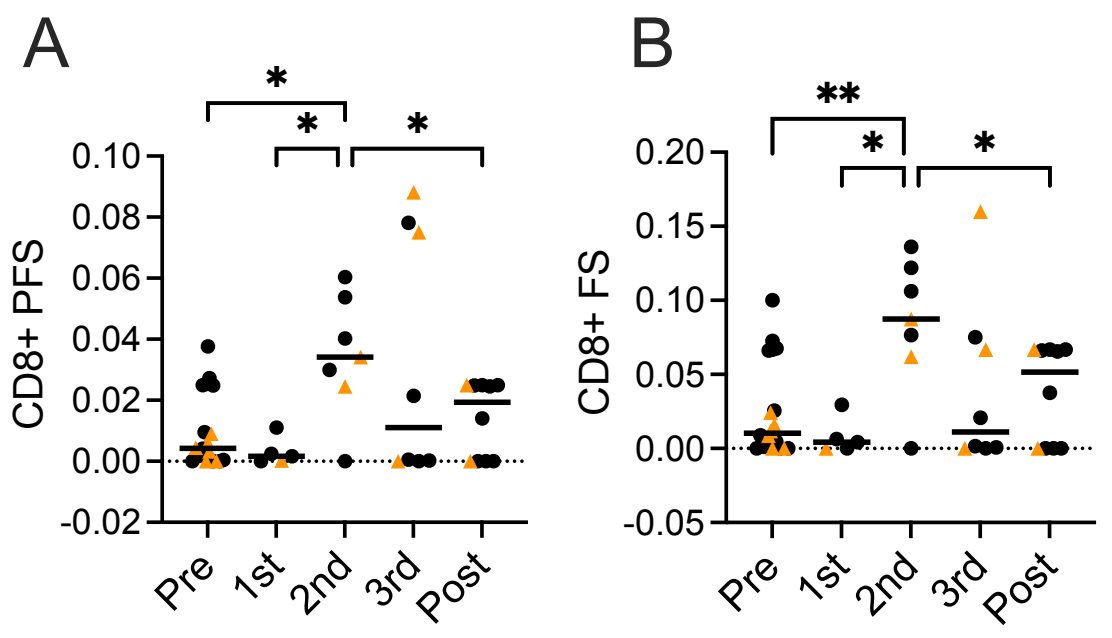
A
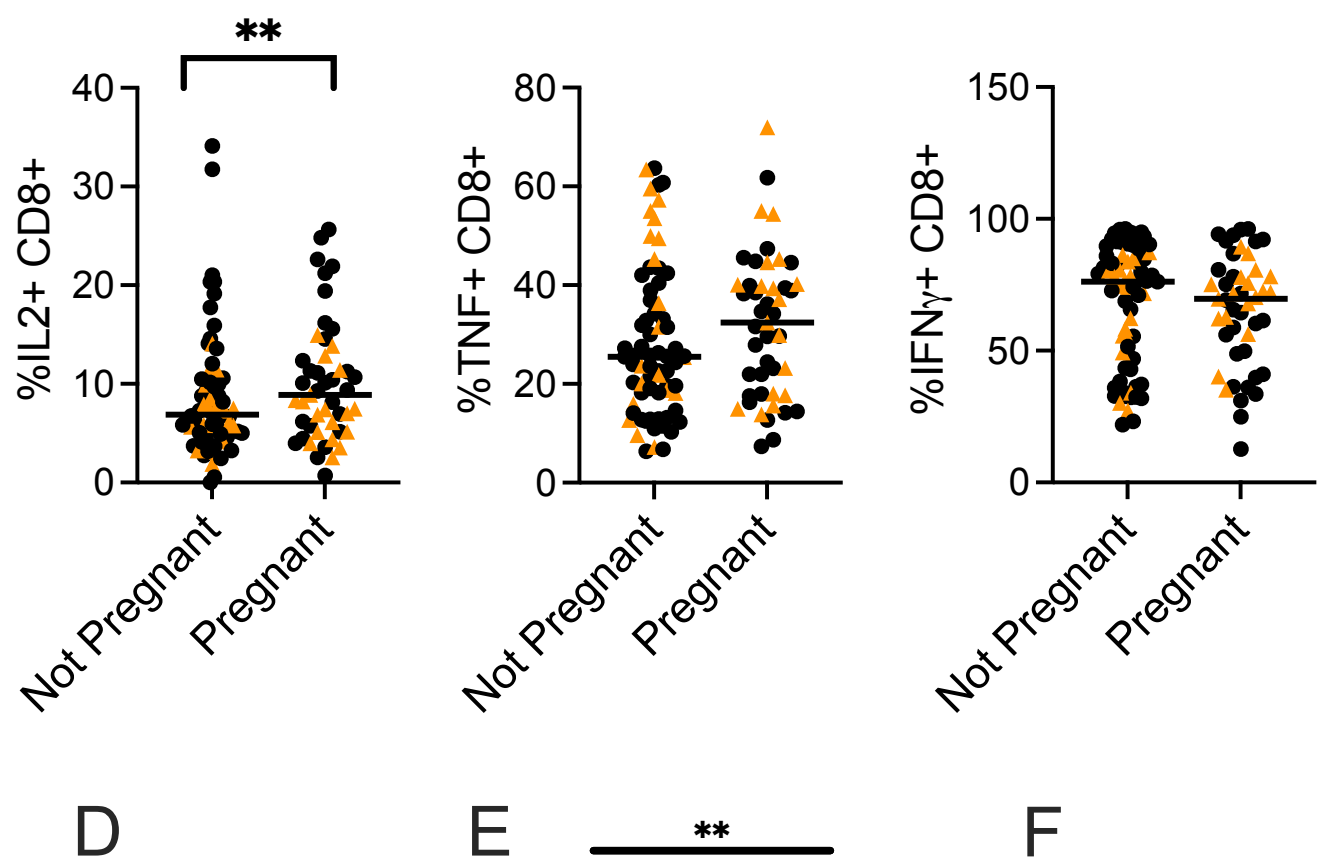

E
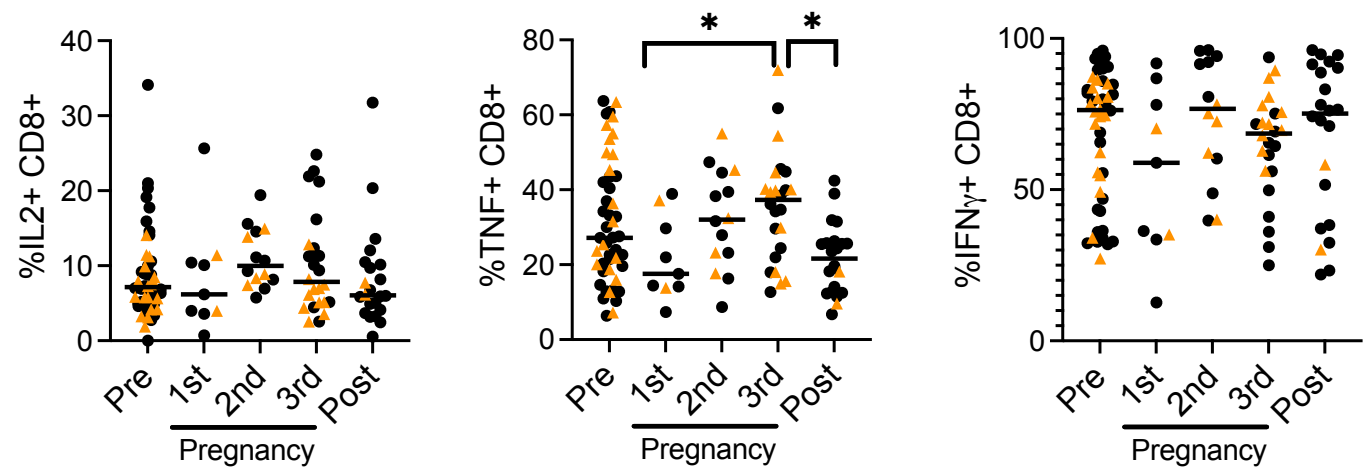


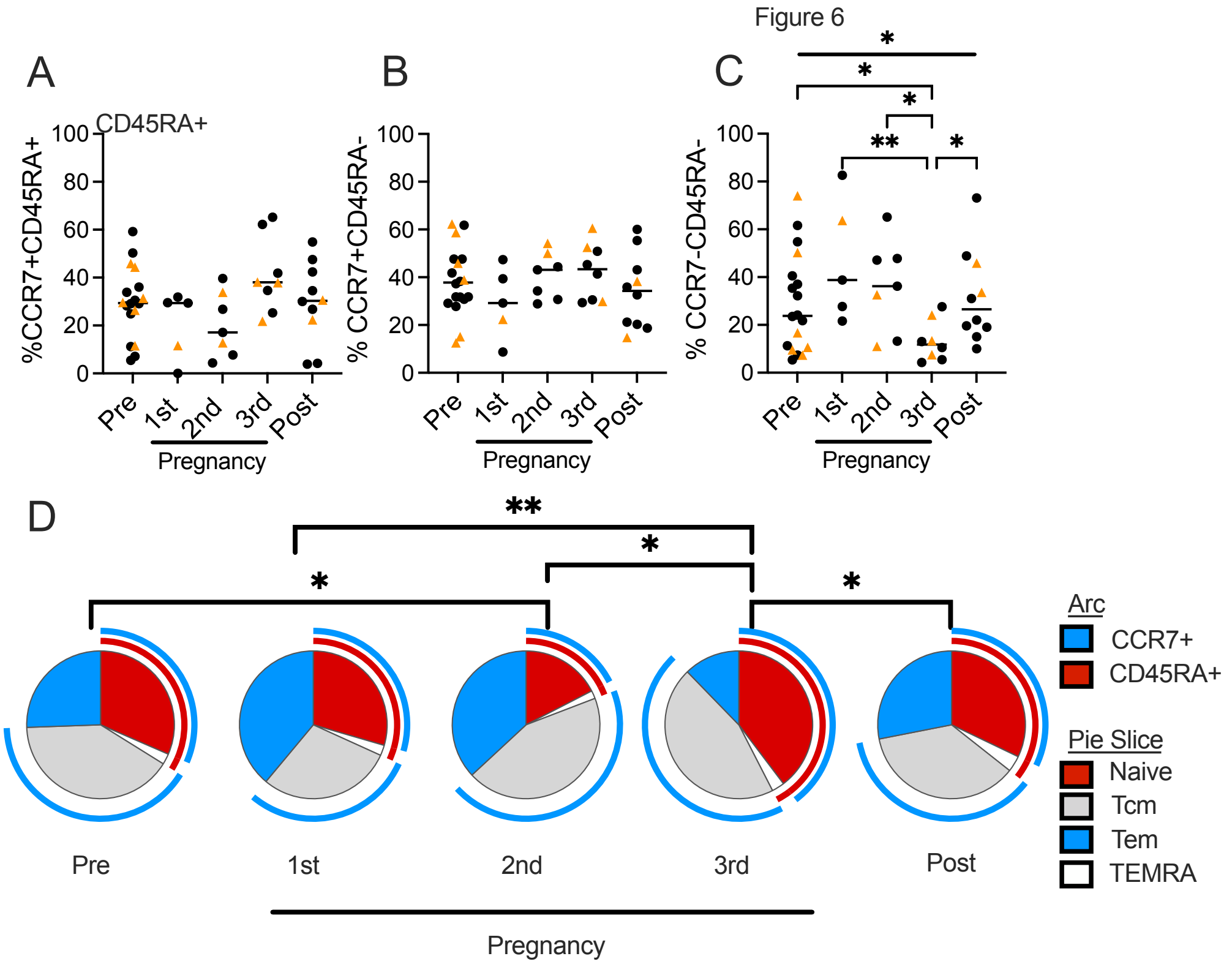




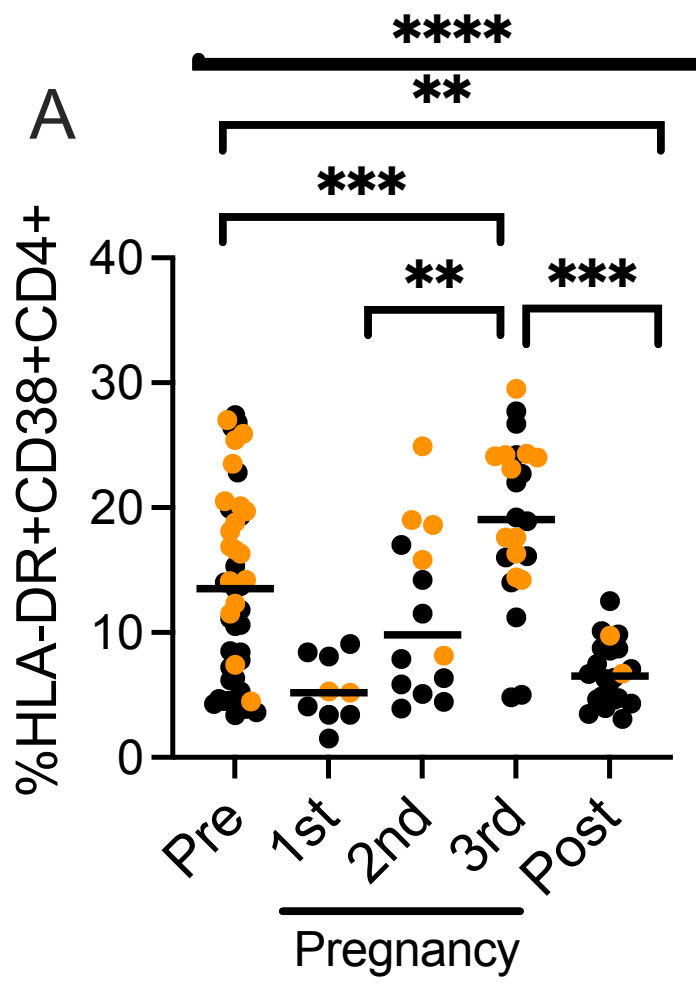

C

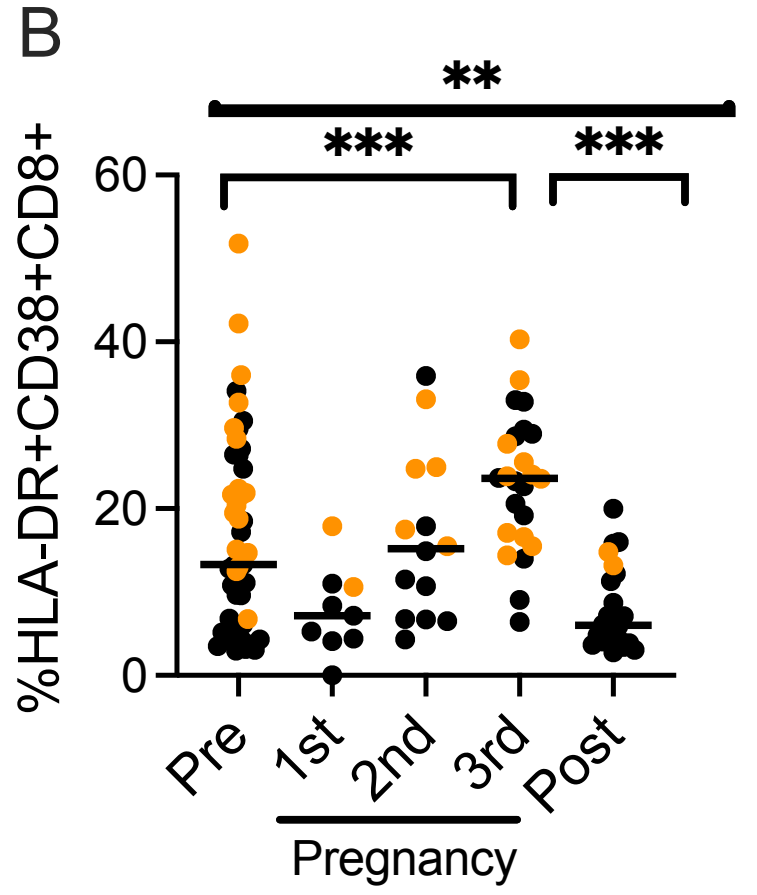

Pre-pregnancy

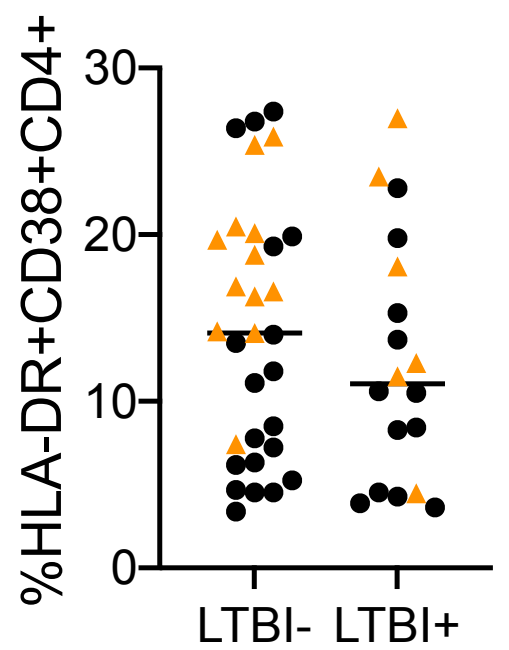

D

Postpartum

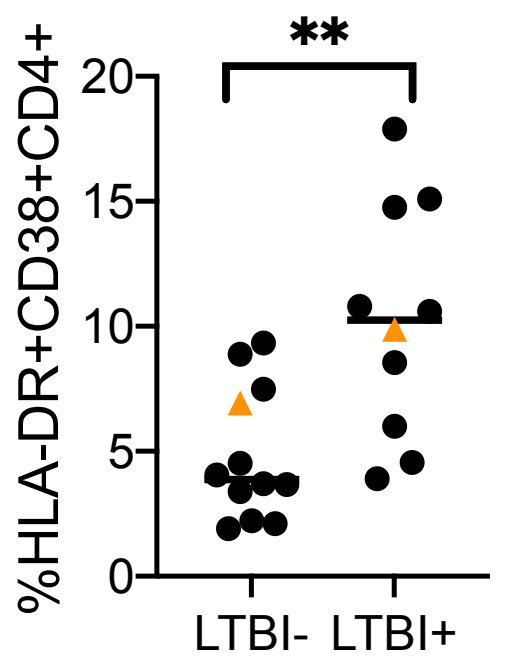




\begin{tabular}{|c|c|c|c|c|c|}
\hline & $\begin{array}{l}\text { Pre- } \\
\text { pregnancy }\end{array}$ & $\begin{array}{l}1^{\text {st }} \\
\text { Trimester }\end{array}$ & $\begin{array}{l}2^{\text {nd }} \\
\text { trimester }\end{array}$ & $\begin{array}{l}3^{\text {rd }} \\
\text { trimester }\end{array}$ & postpartum \\
\hline \multicolumn{6}{|c|}{ Mtb-specific T-cells } \\
\hline CD4+ & $\leftrightarrow$ & $\leftrightarrow$ & $\downarrow$ & $\downarrow \downarrow \downarrow$ & $\leftrightarrow$ \\
\hline CD8+ & $\downarrow \downarrow \downarrow$ & $\downarrow \downarrow$ & $\uparrow \uparrow$ & $\uparrow$ & $\downarrow \downarrow$ \\
\hline \multicolumn{6}{|c|}{ Mitogen stimulated T-cells } \\
\hline CD4+ & $\leftrightarrow$ & $\leftrightarrow$ & $\leftrightarrow$ & $\uparrow \downarrow$ & $\downarrow \uparrow$ \\
\hline $\mathrm{CD} 8+$ & $\leftrightarrow$ & $\leftrightarrow$ & $\uparrow$ & $\leftrightarrow$ & $\leftrightarrow$ \\
\hline \multicolumn{6}{|c|}{ Nonspecific T-cell activation } \\
\hline $\begin{array}{l}\text { Activated T- } \\
\text { cells }\end{array}$ & $\leftrightarrow$ & $\downarrow$ & $\uparrow \uparrow$ & $\uparrow \uparrow \uparrow$ & $\uparrow$ \\
\hline
\end{tabular}

